\title{
Lead potential bioaccumulation in two species of commonly used medicinal plants in Leyte
}

\author{
Honeylene V. Ongy and Beatriz S. Belonias
}

\begin{abstract}
Medicinal plants, especially those that are grown and cultivated in heavily polluted soils, are one source of lead toxicity in humans. This study assessed the $\mathrm{Pb}$ accumulation capacity of two commonly used medicinal plants, Artemisia vulgaris and Plectranthus amboinicus. Bioaccumulation factor, translocation factor and metal extraction ratio of each plant species were also determined. The plants were planted in pots in a controlled experiment and subjected to different concentrations of $\mathrm{Pb}(0-600 \mathrm{ppm})$ for 4 weeks. Both plants showed no visual signs of Pb toxicity at the end of the study. The growth of $A$. vulgaris was not significantly affected by the different levels of $\mathrm{Pb}$ added to the soil. The increase in height of $P$. amboinicus was significantly affected by the $\mathrm{Pb}$ in the soil. The roots accumulated more $\mathrm{Pb}$, followed by the leaves and the stems. $\mathrm{Pb}$ level in plant tissues increased with increased addition of $\mathrm{Pb}$ to the soil. Bioaccumulation factor (BAF) of $A$. vulgaris and $P$. amboinicus was above 1 which means these plants are accumulators of $\mathrm{Pb}$. With a translocation factor $(\mathrm{TF})>1, A$. vulgaris can effectively transfer $\mathrm{Pb}$ from the stems to the shoots while $P$. amboinicus cannot. Of the two plants, $P$. amboinicus was most effective in removing lead from the soil even at high concentrations (600ppm).
\end{abstract}

Keywords: bioaccumulation factor, metal extraction ratio, translocation factor, lead, medicinal plants

\section{INTRODUCTION}

In the Philippines, the use of medicinal plants for disease treatment, prevention, and management is a widely accepted practice. These plants are either grown in the backyard or collected from the wild. Traditional healers usually prepare these medicinal plants as decoctions or infusions. Whole herb consumption is also practiced either as fresh, in dried form or as fresh juice.

Department of Biological Sciences, Visayas State University, Visca, Baybay City, Leyte, 6521 - A Philippines

\footnotetext{
* Corresponding Author. Address: Department of Biological Sciences, Visayas State University, Visca, Baybay City, Leyte,6521 - APhilippines; Email:honeylene.ongy@vsu.edu.ph DOI: $10.32945 /$ atr4021.2018
} 
Based on the study of Chibuike and Obiora (2014), plants have the ability to accumulate essential metals and this ability equally enables them to acquire other nonessential metals. When concentrations within the plant exceed optimal levels, they adversely affect the plant both directly and indirectly. A variety of medicinal plants have the ability to accumulate heavy metals under natural conditions. Heavy metal contents in medicinal plants depend on the plant species (Abou-Arab \& Abou Donia 2000) and location (Amponsah et al 2013). According to Barthwal et al (2008) and Gatebe et al (2012) the geoclimatic conditions of the region, agricultural practices and pollutions decide the level of heavy metals that could accumulate in herbal raw materials.

Like all other heavy metals, $\mathrm{Pb}$ is naturally present in the soil. Geologic and anthropogenic activities increase the concentration of $\mathrm{Pb}$ to amounts that are harmful to both plants and animals. Potential $\mathrm{Pb}$ toxicity in humans comes from the consumption of medicinal plants with high $\mathrm{Pb}$ content in its tissues. Contamination of traditional medicines by heavy metals is of major concern because of the toxicity persistence and bioaccumulative nature of such metals (Dzomba et al 2012). Presence of heavy metals in the tissue of these plants may alter their potential to cure diseases and may even cause toxicity to the person or the animal treated. Singh and Kalamdhad (2011) mentioned that $\mathrm{Pb}$ affects children and leads to the poor development of the grey matter of the brain, thereby resulting in poor intelligence quotient (IQ). Butrick et al (2007) found that the children in Leyte had the highest mean $(8.5 \mu \mathrm{g} / \mathrm{dl})$ blood Pb level among the 11 provinces they had surveyed. Genuis and Kelln (2015) found that elevated levels of $\mathrm{Pb}$ can be linked to hypertension and can cause memory impairment and dementia in adults. Thus quality assurance of plant material is indispensable to ensure reproducible quality of herbal medicine, which will contribute not only to its efficacy, but also to its safety.

In this study, two common and widely used plants for medicinal purposes were tested for their ability to absorb and accumulate lead $(\mathrm{Pb})$. Artemisia vulgaris and Plectranthus amboinicus are well known medicinal plants in Leyte as well as in the whole Philippines. These are commonly cultivated and grown around the house because they grow fast and are well adapted to any soil type.

This study aimed to determine which part of the medicinal plant accumulates the highest and lowest levels of $\mathrm{Pb}$, identify which medicinal plant species can tolerate the highest level of $\mathrm{Pb}$ in their tissues; and compare the $\mathrm{Pb}$ bioaccumulation factor, extraction ratio, and translocation factor among medicinal plants used.

\section{MATERIALS AND METHODS}

\section{Preparation of Potting Medium}

For the potting medium, one part garden soil, two parts compost and one part rice hull were mixed. The mixture was sterilized by heating in a large vat for two hours to kill soil-borne pathogens. In each 6-inch wide-mouthed polyethylene pot, one kilogram of the potting medium was placed. 
Lead potential bioaccumulation in two species

\section{Experimental Design and Treatments}

The experiment was laid out in a Completely Randomized Design (CRD) with six concentrations of $\mathrm{Pb}$ as treatments having three replications for every treatment and three sample plants per treatment per replication. The levels of $\mathrm{Pb}$ used were based on the study conducted by Ignatius et al (2014) showing that Plectranthus amboinicus can tolerate up to $200 \mathrm{mg} / \mathrm{kg}$ level of $\mathrm{Pb}$. The different $\mathrm{Pb}$ concentrations used as treatments were 100, 200, 300, 400, 500 and 600 ppm Pb, with distilled water as control.

\section{Plant Establishment}

Young plants or cuttings of the identified medicinal plants were collected. Five plants were initially grown in each polyethylene pot that contained the sterilized potting medium. The plants were allowed to grow and establish in the screenhouse of the Department of Biological Sciences, Visayas State University, Baybay City, Leyte until the plants attained more or less uniform size. After one week, the number of plants in each pot was thinned to three per pot by removing the unhealthy ones. All plants in each polyethylene pot remained in the experimental screenhouse and grown under protected condition for another two weeks. Watering and weeding were done whenever necessary.

\section{Preparation of Lead Solution and Application of Treatments}

A 1500ppm stock solution of $\mathrm{Pb}$ acetate $\left(\mathrm{Pb}\left(\mathrm{CH}_{3} \mathrm{COO}\right)_{2}\right)$ was prepared by weighing $2.36 \mathrm{~g}$ of $\mathrm{Pb}$ acetate on a top loading balance and dissolved in $1000 \mathrm{~mL}$ distilled water to make a $1 \mathrm{~L}$ stock solution using a $1000-\mathrm{mL}$ volumetric flask. One liter of each of the various treatment solutions was prepared per replication from this stock solution. Two-hundred fifty (250) $\mathrm{ml}$ of each treatment solution was added into each pot every week for two weeks. A plastic pan was positioned under each pot to collect excess solution that would drip from the pot after every application. Collected drippings were poured back into the pot.

\section{Plant Tissue and Soil Analysis}

After one month, the plants grown in the screenhouse were harvested by carefully taking out each plant from the soil. The harvested plants were washed with tap water to remove dirt and patted dry using tissue paper. These were separated into roots, stems and leaves and placed in labeled brown paper bags and were ovendried at $70^{\circ} \mathrm{C}$ for 48 hours. The oven-dried plant parts were then finely ground using a plant tissue grinder at the Department of Agronomy and Soil Science, VSU. The ground tissue samples were sent to the Central Analytical Services Laboratory, VSU for the analysis of total $\mathrm{Pb}$ content.

One composite soil sample was obtained from the potting medium before the start of the experiment and one composite sample per treatment replication at the termination of the experiment. These were air-dried and sieved using a 40-um sieve. About $10 \mathrm{~g}$ of each dried sample was analyzed at the Central Analytical Service Laboratory of VSU for total $\mathrm{Pb}$ content, $\mathrm{pH}$ and organic matter. 


\section{Statistical Analysis}

All data collected were subjected to one-way analysis of variance (ANOVA) to determine any significant effects of the $\mathrm{Pb}$ present or added to the soil to the amount of $\mathrm{Pb}$ in the medicinal plant tissues. A significance level of $(P=0.05)$ was used throughout the study.

\section{Data Collection}

Growth parameters like height and weight, as well as total lead content of the soil were measured at the start and at the end of the experiment. The total lead content of the roots, stems and leaves were measured at harvest. Pb content was analyzed using the Aqua Regia Method (DIN ISO $11466 \mathrm{nd}$ ).

Based on the above data, the following were computed:

1. Bioaccumulation factor (BAF) - This was computed using the method by (Rezvani \& Zaefarian 2011):

where:

$$
\mathrm{BAF}=\mathrm{C}_{\text {shoot }} / \mathrm{C}_{\text {soil }}
$$

$\mathrm{C}_{\text {shoot }}=\mathrm{Pb}$ concentration of the shoot

$\mathrm{C}_{\text {soil }}=\mathrm{Pb}$ concentration of the soil

2. Translocation factor (TF) - This was computed by (Rezvani \& Zaefarian 2011):

where:

$$
\mathrm{TF}=\mathrm{C}_{\text {shoot }} / \mathrm{C}_{\text {root }}
$$

$$
\begin{aligned}
& \mathrm{C}_{\text {shoot }}=\mathrm{Pb} \text { concentration in the shoot } \\
& \mathrm{C}_{\text {roots }}=\mathrm{Pb} \text { concentration in the roots }
\end{aligned}
$$

3. Metal Extraction ratio (MER) - This was computed by (Rezvani \& Zaefarian 2011):

where:

$$
\operatorname{MER}=\left(\mathrm{C}_{\text {plant }} \times \mathrm{M}_{\text {plant }} / \mathrm{C}_{\text {soil }} \times{ }_{\text {Mrooted zone }}\right) \times 100
$$

$$
\begin{aligned}
& \mathrm{C}_{\text {plant }}=\mathrm{Pb} \text { concentration in the harvested component of the } \\
& \text { plant biomass } \\
& \begin{aligned}
& \mathrm{M}_{\text {plant }}= \text { mass of the harvestable aboveground biomass } \\
& \text { produced in one harvest }
\end{aligned} \\
& \mathrm{C}_{\text {soil }}=\text { Pb concentration in the soil volume } \\
& \mathrm{M}_{\text {rooted zone }}=\text { mass of the soil volume rooted by the species } \\
& \text { under study }
\end{aligned}
$$


Lead potential bioaccumulation in two species

\section{RESULTS AND DISCUSSION}

\section{Visual Symptoms of Lead Toxicity}

During the duration of the experiment, no visual morphological symptoms of $\mathrm{Pb}$ toxicity were observed in Artemisia vulgaris and Plectranthus amboinicus. Shown in Figures 1 and 2 are $A$. vulgaris and $P$. amboinicus plants growing vigorously even at the highest concentration of 600ppm. This shows that both plant species can tolerate high levels of $\mathrm{Pb}$ without showing visual toxicity symptoms.

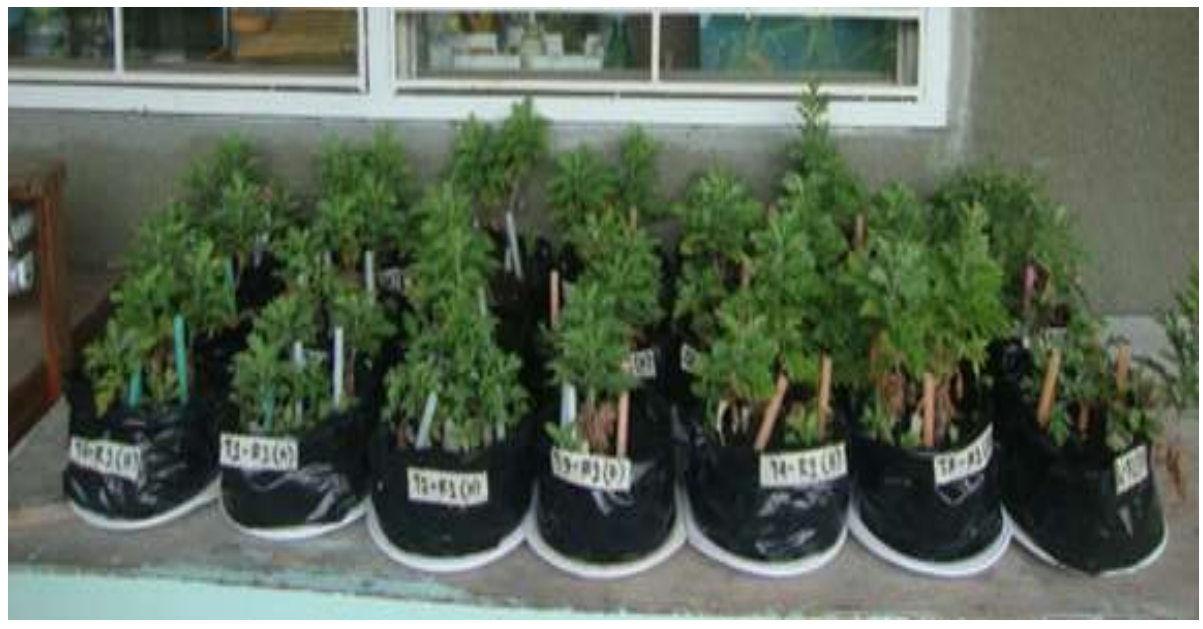

Figure 1. Artemisia vulgaris plants on the $4^{\text {th }}$ week of the experiment

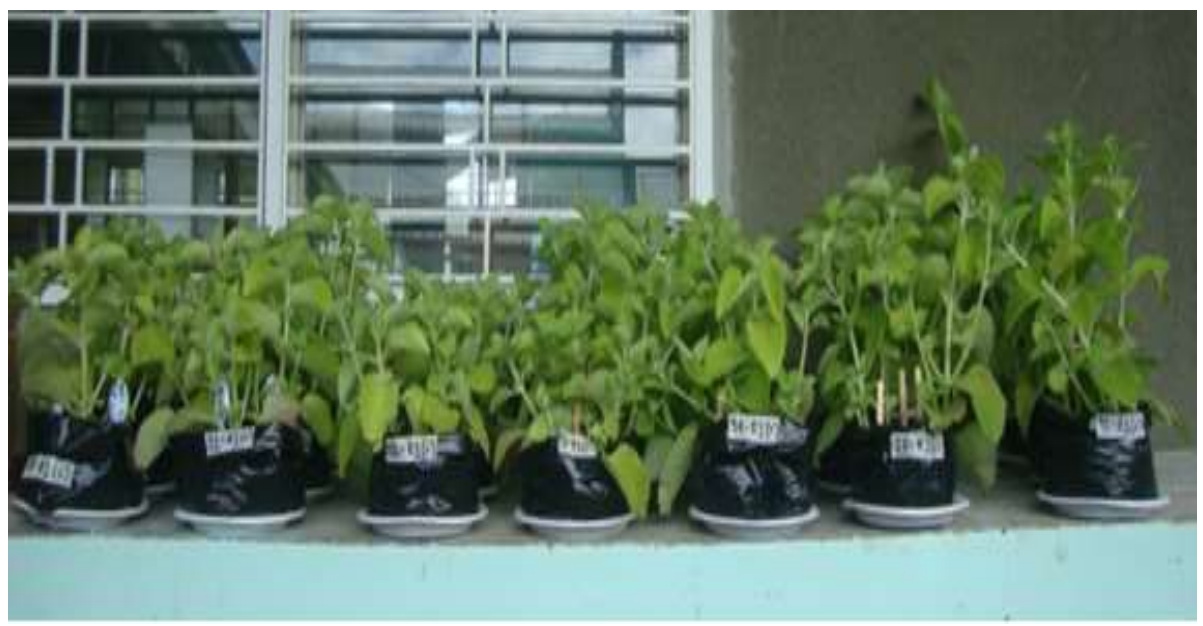

Figure 2. Plectranthus amboinicus plants on the $4^{\text {th }}$ week of the experiment 
Effects of Lead $(\mathrm{Pb})$ on plant growth of Artemisia vulgaris and Plectranthus amboinicus

\section{Plant height and weight}

$\mathrm{Pb}$ is not an essential element for plants, but they absorb it when it is present in their environment. After one month of treating the plants with different concentrations of $\mathrm{Pb}$, final plant height $(\mathrm{cm})$, plant height increment $(\mathrm{cm})$, final fresh weight (g), fresh weight increment (g), final dry weight $(\mathrm{g})$ and percent dry matter were taken and recorded. Artemisia vulgaris may have shown a decrease in plant height, final fresh weight, fresh weight increment, dry weight and percent dry matter at $600 \mathrm{ppm} \mathrm{Pb}$ concentration but statistically, the different $\mathrm{Pb}$ concentrations had no effect on the overall growth of the plants (Table 1). Results suggest that $A$. vulgaris is a potential $\mathrm{Pb}$ accumulator. According to Dalvand et al (2014), some species of Artemisia are effective for phytoremediation. A study by Belonias (2013) showed that $\mathrm{Pb}$ application to Coleus scutellaroides did not significantly affect the dry matter content of the plants. Plectranthus amboinicus on the other hand, had a highly significant effect from the different $\mathrm{Pb}$ concentrations except for the final fresh weight increment (Table 2). The study by Ignatius et al (2014) revealed that $P$. amboinicus is tolerant to a wide range of $\mathrm{Pb}$ concentrations and nutrient deficiency. The plant can accumulate considerable amount of $\mathrm{Pb}$ and suggests that it can be considered for the clean-up of lead-contaminated water.

Table 1. Final plant height $(\mathrm{cm})$, height increment $(\mathrm{cm})$, final fresh weight $(\mathrm{g})$, fresh weight increment $(\mathrm{g})$ and dry weight of Artemisia vulgaris as influenced by different levels of lead $(\mathrm{Pb})$

\begin{tabular}{|c|c|c|c|c|c|c|}
\hline Treatments & $\begin{array}{c}\text { Final } \\
\text { Plant } \\
\text { Height } \\
(\mathrm{cm})\end{array}$ & $\begin{array}{l}\text { Height } \\
\text { Increment } \\
(\mathrm{cm})\end{array}$ & $\begin{array}{c}\text { Final } \\
\text { Fresh } \\
\text { Weight } \\
\text { (g) }\end{array}$ & $\begin{array}{c}\text { Fresh } \\
\text { Weight } \\
\text { Increment } \\
\text { (g) }\end{array}$ & $\begin{array}{c}\text { Dry } \\
\text { Weight } \\
\text { (g) }\end{array}$ & $\begin{array}{c}\text { Percent } \\
\text { Dry } \\
\text { Matter } \\
(\%)\end{array}$ \\
\hline T0 (Control) & 19.26 & 2.27 & 17.20 & 11.47 & 6.23 & 36.43 \\
\hline T1 (100 ppm Pb) & 17.56 & -0.04 & 15.70 & 10.46 & 5.93 & 37.86 \\
\hline T2 (200 ppm Pb) & 18.60 & -0.19 & 17.67 & 11.80 & 6.70 & 38.19 \\
\hline T3 (300 ppm Pb) & 18.27 & 0.36 & 14.70 & 9.69 & 6.83 & 44.56 \\
\hline T4 (400 ppm Pb) & 17.53 & -1.51 & 21.73 & 14.49 & 6.93 & 31.59 \\
\hline T5 (500 ppm Pb) & 20.19 & 2.31 & 20.07 & 13.38 & 6.00 & 29.78 \\
\hline T6 (600 ppm Pb) & 16.44 & 1.22 & 11.53 & 7.69 & 3.33 & 28.78 \\
\hline F-test & ns & ns & ns & ns & ns & ns \\
\hline
\end{tabular}

ns - not significant 
Lead potential bioaccumulation in two species

Table 2. Final plant height $(\mathrm{cm})$, height increment $(\mathrm{cm})$, final fresh weight $(\mathrm{g})$, fresh weight increment $(\mathrm{g})$ and dry weight of Plectranthus amboinicus as influenced by different levels of lead $(\mathrm{Pb})$

\begin{tabular}{|c|c|c|c|c|c|c|}
\hline Treatments & $\begin{array}{c}\text { Final } \\
\text { Plant } \\
\text { Height } \\
(\mathrm{cm})\end{array}$ & $\begin{array}{l}\text { Height } \\
\text { Increment } \\
(\mathrm{cm})\end{array}$ & $\begin{array}{c}\text { Final } \\
\text { Fresh } \\
\text { Weight } \\
\text { (g) }\end{array}$ & $\begin{array}{c}\text { Fresh } \\
\text { Weight } \\
\text { Increment } \\
\text { (g) }\end{array}$ & $\begin{array}{l}\text { Dry } \\
\text { Weight } \\
\text { (g) }\end{array}$ & $\begin{array}{c}\text { Percent } \\
\text { Dry } \\
\text { Matter } \\
(\%)\end{array}$ \\
\hline T0 (Control) & 28.35 & 10.24 & 63.71 & 53.27 & 13.67 & 21.48 \\
\hline T1 (100 ppm Pb) & 28.87 & 10.26 & 83.90 & 71.16 & 17.80 & 21.13 \\
\hline T2 (200 ppm Pb) & 24.73 & 5.81 & 60.00 & 49.75 & 12.67 & 21.28 \\
\hline T3 (300 ppm Pb) & 28.21 & 8.21 & 74.54 & 61.84 & 15.83 & 21.35 \\
\hline T4 (400 ppm Pb) & 31.04 & 13.00 & 75.28 & 62.58 & 15.77 & 20.85 \\
\hline T5 (500 ppm Pb) & 33.51 & 15.71 & 85.46 & 67.75 & 17.97 & 21.01 \\
\hline T6 (600 ppm Pb) & 40.32 & 21.84 & 72.92 & 60.52 & 14.43 & 19.10 \\
\hline F-test & ** & ** & * & ns & * & ns \\
\hline
\end{tabular}

** - highly significant, * - significant, ns - not significant

\section{Lead concentrations in the plant tissues}

$\mathrm{Pb}$ contents in A. vulgaris tissues where all above the WHO permissible limit of $10 \mathrm{mg} / \mathrm{kg}$ except for roots in $\mathrm{TO}$. The $\mathrm{Pb}$ content also increased with increase in the amount of $\mathrm{Pb}$ applied. Results for the leaves, stems and roots were highly significant (Figure 3). Lead concentrations in the leaves, stems and roots of $P$. amboinicus increased significantly with increased Pb supply (Figure 4). Results suggests that $P$. amboinicus is a $\mathrm{Pb}$ accumulator. Although lead levels where high, normal plant growth was still observed. Based on the study of Ignatius et al (2014), Plectranthus amboinicus showed an exponential increase in $\mathrm{Pb}$ removal in the initial stages of $\mathrm{Pb}$ application but showed gradual decline overtime. As the plant's roots are exposed to higher $\mathrm{Pb}$ concentrations, $\mathrm{Pb}$ uptake by the plant decreased which is indicative of a fast attainment of saturation state in the plants.

The study of Maziah et al (2011) on Centella asiatica found that most heavy metals, including $\mathrm{Pb}$, had the highest accumulation in the roots, then in the leaves, and in the stems. The constant contact of the root with the metals in the soil and presence of root hairs increasing its surface area could be the main reasons for this. Balabane et al (2000) also obtained the same result where the concentrations of metals in roots were greater than concentrations in leaves, indicating significant metal immobilization by the roots. Some strategies used by plants against $\mathrm{Pb}$ toxicity are sequestration of $\mathrm{Pb}$ into vacuoles by the formation of complexes; binding of lead by phytochelatins, glutathione, and amino acids; and synthesis of osmolytes (Dumat et al 2011). Verma and Dubey (2003) mentioned that Pb retention in the roots is based on binding of $\mathrm{Pb}$ to ion exchangeable sites on the cell wall and extracellular precipitation, mainly in the form of $\mathrm{Pb}$ carbonate deposited in the cell wall. They explained that one reason for the high accumulation of $\mathrm{Pb}$ in roots compared to shoots is that $\mathrm{Pb}$ moves predominantly into the root apoplast and thereby in a radial manner across the cortex and accumulates near the endodermis. Thus, the endodermis acts as a partial barrier to the movement of $\mathrm{Pb}$ between the root and shoot. Fahr et al (2013) observed in Allium sativum that endocytotic and exocytotic processes are activated as defense mechanism as soon 
as excessive $\mathrm{Pb}$ ions enter the cytoplasm to protect the cells against $\mathrm{Pb}$ toxicity. Invaginations of plasmalemma and some vesicles from dictyosomes and reticulum (ER) prevents the free circulation of $\mathrm{Pb}$ ions in the cytplasm. The plant vacuole serves as a storage site for excess $\mathrm{Pb}$ in the root.

Since $\mathrm{Pb}$ tends not to migrate readily in the soil, it can build up in surface layers. Thus shallow rooted plants are more likely to become $\mathrm{Pb}$ contaminated. Balabane et al (2000) found that aging leaves have greater concentration of $\mathrm{Pb}$ than young leaves, as in the case of Armeria maritima ssp. Halleri, suggesting a detoxification mechanism by leaf fall. Several studies confirmed high accumulation of $\mathrm{Pb}$ and other heavy metals in leafy vegetables than non-leafy vegetables (Dey \& Dwivedi 2002, Feleafel \& Mirdad 2013, Li et al 2009, Jung \& Thornton 1996, Micó et al 2007), this is due to the fact that most leafy vegetables are shallow rooted plants. Stems had the lowest metal accumulation because it serves only as a channel for the passage of metals to the other plant parts.

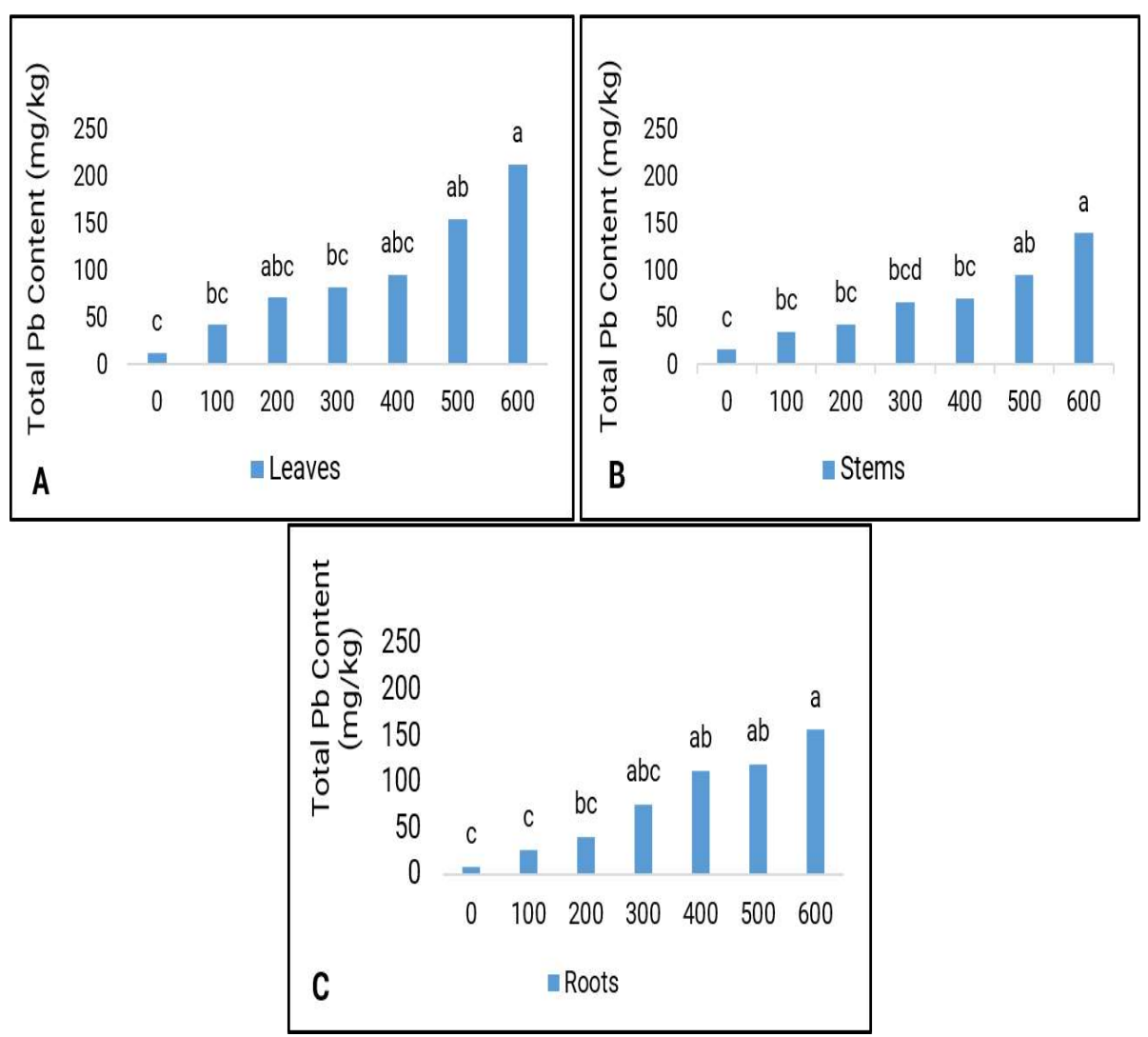

Figure 3. Mean total lead content ( $\mathrm{mg} / \mathrm{kg}$ ) in the leaves (A), stems (B) and roots (C) of Artemisia vulgaris at the end of the experiment (Bars with same letter are not significantly different at $5 \%$ level of significance) 
Lead potential bioaccumulation in two species

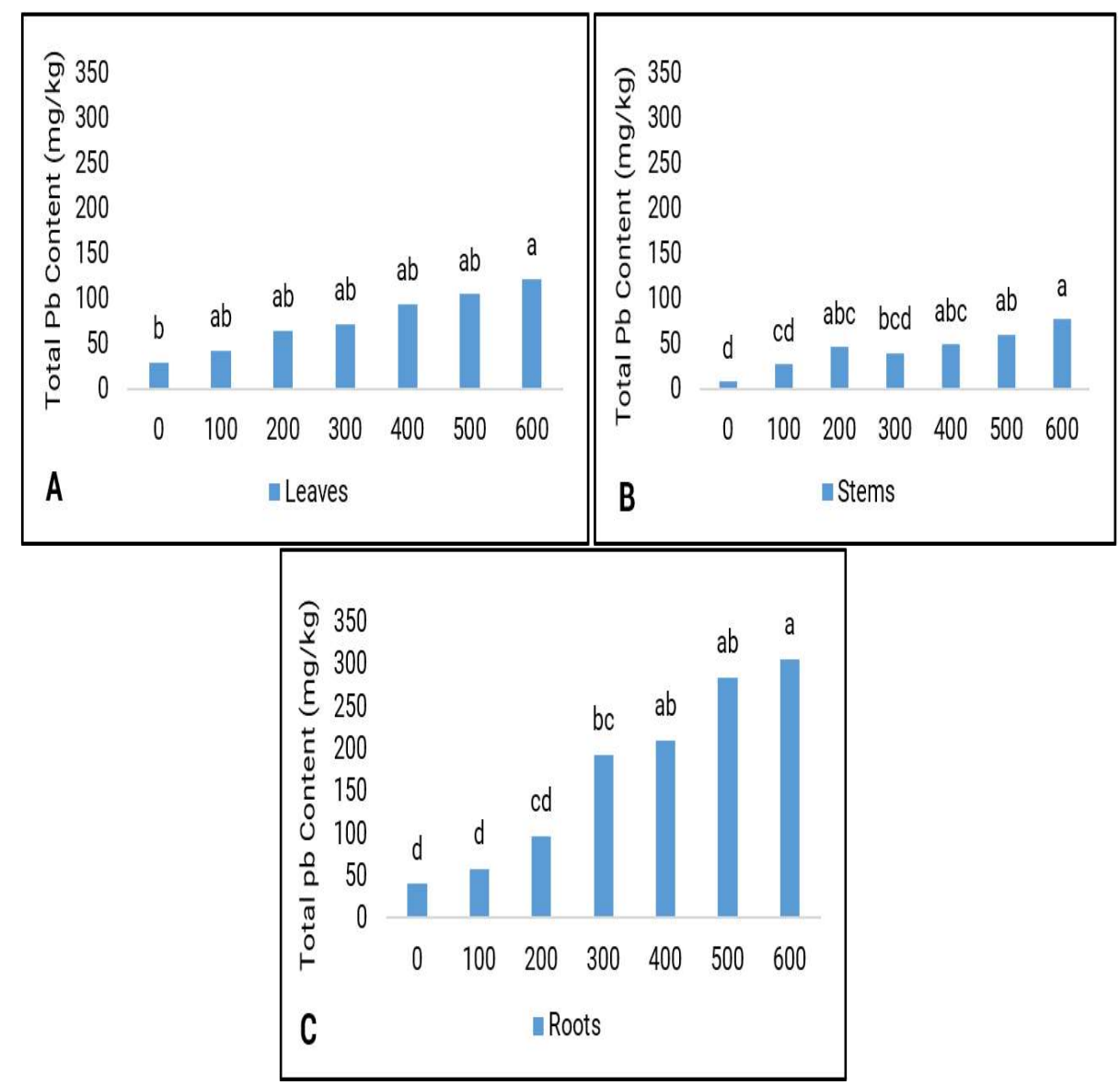

Figure 4. Mean total lead content $(\mathrm{mg} / \mathrm{kg})$ in the leaves, stems and roots of Plectranthus amboinicus at the end of the experiment (Bars with same letter are not significantly different at $5 \%$ level of significance)

\section{Soil $\mathrm{pH}$, soil $\mathrm{Pb}$ and organic matter}

Dumat et al (2011) mentioned that the behavior of $\mathrm{Pb}$ in soil, and uptake by plants, is controlled by its speciation and by the soil $\mathrm{pH}$, soil particle size, cationexchange capacity, root surface area, root exudation, and degree of mycorrhizal transpiration. At the start of the experiment, the initial soil pH for the soil medium used was 6.35. Soil pH for both plants after the experiments remained near neutral and did not vary significantly among the treatments and among the type of plant. According to Akan et al (2013), heavy metal mobility decreases with increasing soil $\mathrm{pH}$ (8 and above) due to precipitation of hydroxides, carbonates or formation of insoluble organic complexes. Under acidic condition, heavy metals are more mobile and become more available below ground and vertically upward for plant uptake (Nazareno et al 2011). 
The soil medium had an initial soil OM of $3.67 \%$ and still showed no significant difference between treatments at the end of the experiment. Tables 3 and 4 show the average soil OM (\%) of the soil medium applied with different concentrations of $\mathrm{Pb}$. Result was the same for both plants. According to Li et al (2016), increased addition of dissolved organic matter to Brassica chinensis significantly increased $\mathrm{Pb}$ in the roots. This is in contrast to the statement of Chibuike and Obiora (2014) that organic matter together with hydrous ferric oxide have been shown to decrease heavy metal availability through immobilization of these metals.

Table 3. Mean soil pH, soil Pb and organic matter content (\%) of soil medium planted with Artemisia vulgaris at the termination of the experiment

\begin{tabular}{|c|c|c|c|}
\hline Treatments & Soil PH & Ssoil Pb (mg/kg) & $\begin{array}{c}\text { Soil Organic } \\
\text { Matter Content (\%) }\end{array}$ \\
\hline T0 (Control) & 6.63 & 3.50 & 3.76 \\
\hline T1 (100 ppm Pb) & 6.75 & 60.6 & 3.85 \\
\hline T2 (200 ppm Pb) & 6.76 & 90.1 & 4.17 \\
\hline T3 (300 ppm Pb) & 6.82 & 99.6 & 3.86 \\
\hline $\mathrm{T} 4$ (400 ppm Pb) & 6.65 & 108 & 4.32 \\
\hline T5 (500 ppm Pb) & 6.75 & 112 & 3.78 \\
\hline T6 (600 ppm Pb) & 6.85 & 115 & 3.56 \\
\hline F-test & ns & ** & ns \\
\hline
\end{tabular}

$\star *$ - highly significant, $n s-$ not significant

Table 4. Mean soil $\mathrm{pH}$, soil $\mathrm{Pb}$ and organic matter content (\%) of soil medium planted with Plectranthus amboinicus at the termination of the experiment

\begin{tabular}{|c|c|c|c|}
\hline Treatments & Soil PH & Soil Pb (mg/kg) & $\begin{array}{c}\text { Soil Organic Matter Content } \\
(\%)\end{array}$ \\
\hline T0 (Control) & 6.20 & 4.97 & 4.11 \\
\hline T1 (100 ppm Pb) & 6.20 & 70.6 & 4.04 \\
\hline T2 (200 ppm Pb) & 6.28 & 95.8 & 4.06 \\
\hline T3 (300 ppm Pb) & 6.32 & 104 & 3.26 \\
\hline T4 (400 ppm Pb) & 6.25 & 112 & 3.93 \\
\hline T5 (500 ppm Pb) & 6.25 & 115 & 3.67 \\
\hline T6 (600 ppm Pb) & 6.32 & 115 & 4.02 \\
\hline F-test & ns & ** & ns \\
\hline
\end{tabular}

$* *$ - highly significant, $\mathrm{ns}-$ not significant

\section{Bioaccumulation factor, metal extraction ratio and translocation factor of lead}

Bioaccumulation is defined as a process in which a chemical substance is absorbed by an organism in all routes of possible exposure in its natural environment (Arnot \& Gobas 2006). According to Cheraghi et al (2011), a plant's ability to accumulate metals from soils can be estimated using the BAF/BCF and a plant's ability to translocate metals from the roots to the shoots is measured using the translocation factor (TF). A plant is considered for heavy metal phytoextraction if it has both a bioaccumulation factor and translocation factor greater than one (BCF > 1). Table 5 shows the average bioaccumulation factor, translocation factor and metal extraction ratio of Artemisia vugaris and Plectranthus amboinicus. 
Lead potential bioaccumulation in two species

Table 5. Average bioaccumulation factor (BF), metal extraction ratio (MER) and translocation factor (TF) in Artemisia vulgaris and Plectranthus amboinicus

\begin{tabular}{llll}
\hline \multicolumn{1}{c}{ Scientific Name } & BAF & TF & MER \\
\hline Artemisia vulgaris & 2.71 & 2.46 & 3.94 \\
Plectranthus amboinicus & 2.13 & 0.81 & 31.0 \\
\hline
\end{tabular}

A BAF $>1$ was observed in both $A$. vulgaris (2.713) and $P$. amboinicus (2.129). Result suggests that both $A$. vulgaris and $P$. amboinicus are effective for removing $\mathrm{Pb}$ from contaminated soils.

Artemisia vulgaris has a TF $>1$ (2.462) while $P$. amboinicus has $\mathrm{TF}<1$ (0.811). A study by Ignatius et al (2014) on $P$. amboinicus treated with $5-200 \mathrm{mg} / \mathrm{kg}$ of $\mathrm{Pb}$ showed the same result, which indicates poor translocation of $\mathrm{Pb}$ from root to aerial parts. TF values decreased with increased level of $\mathrm{Pb}$. Low translocation of $\mathrm{Pb}$ indicates that the after plants were unwilling to transfer $\mathrm{Pb}$ from their roots to shoots possibly due to $\mathrm{Pb}$ toxicity. Translocation factor above 1 also indicates the capability of the plant to transport metals from roots to shoot and the existence of hypertolerance ability (Chibuike \& Obiora 2014). The process of evapotranspiration helps pump the absorbed nutrients and other substances from the roots to the shoots, which is accountable for the contamination into plant leaves and shoots if atmospheric $\mathrm{Pb}$ pollution is very minimal (Tangahu et al 2011). Leaves accumulate metals because they serve as a storage site for products that are later used for further metabolic activities (Maziah et al 2011). Plants with both BAF and TF $>1$ have the potential to be used in phytoextraction. Plants with $B A F>1$ and $T F<1$ have the potential for phytostabilization. The process of phytoextraction generally requires the translocation of heavy metals to the easily harvestable plant parts, ie shoots (Yoon et al 2006) and while phytostabilization process requires the strong ability to reduce metal translocation from roots to shoots (Cheraghi et al 2011).

\section{CONCLUSION AND RECOMMENDATION}

Plectranthus amboinicus is a medicinal plant that can be considered as a $\mathrm{Pb}$ accumulator. $\mathrm{Pb}$ accumulation is highest in roots, followed by leaves and the stems. P. amboinicus and $A$. vulgaris are good phytoextractors of $\mathrm{Pb}$ because they can effectively remove $\mathrm{Pb}$ from the ground and transfer it to the shoot/leaves. But $A$. vulgaris is more effective in transferring $\mathrm{Pb}$ to the leaves from the root.

Consuming contaminated fresh leaves or leaf extracts of $A$. vulgaris and $P$. amboinicus pose a risk of higher $\mathrm{Pb}$ transferred to the body. Collection of plants for medicinal use should be from pollution-free natural habitats. Cultivation of medicinal plants, as opposed to collection from the wild, will allow for controlled growth and monitoring of potentially hazardous parameters. Every medicinal plant sample should be tested for contaminant load before processing it further for medication. 
Ongy \& Belonias

\section{REFERENCES}

Abou-Arab AA and Abou Donia MA. 2000. Heavy metals in Egyptian spices and medicinal plants and the effect of processing on their levels. Journal of Agricultural and Food Chemistry, 48(6):2300-4

Akan JC, Audu SI, Mohammed Z \& Ogugbuaja VO. 2013. Assessment of heavy metals, $\mathrm{pH}$, organic matter and organic carbon in roadside soils in Makurdi Metropolis, Benue State, Nigeria. Journal of Environmental Protection, 4:618628

Amponsah IK, Annan K, Dickson RA \& Nooni IK. 2003. The heavy metal contents of some selected medicinal plants sampled from different geographical locations. Pharmacognosy Research, 5(2):103-108

Arnot JA and Gobas F. 2006. A Review of Bioconcetration factor (BCF) and Bioaccumulation factor (BAF) assessments for organic chemicals in aquatic organsims. Environmental Reviews, 14:257-297

Balabane M, Dahmani-Muller H, Gélie B \& van Oort F. 2000. Strategies of heavy metal uptake by three plant species growing near a metal smelter. Environmental Pollution, 109 (2):231-238

Barthwal J, Nair S \& Kakkar P. 2008. Heavy metal accumulation in medicinal plants collected from environmentally different sites. Biomedical and Environmental Sciences, 21:319-324

Belonias TDS. 2013. Bioaccumulation of lead in Mayana (Coleus scutellarioides \{L.\} Benth. Undergraduate Thesis, Visayas State University, Baybay City, Leyte Philippines. Unpublished

Butrick E, Peabody JW, Quimbo SA, Riddell TJ, Solon O \& Tan CC. 2007. Elevated blood-lead levels among children living in the rural Philippines. Bulletin of the World Health Organization, 85(9):674-680

Cheraghi M, Lorestani B \& Yousefi N. 2011. Phytoremediation Potential of Native Plants Growing on a Heavy Metals Contaminated Soil of Copper mine in Iran. World Academy of Science, Engineering and Technology. (pp6)

Chibuike GU and Obiora SC. 2014. Heavy Metal Polluted Soils: Effect on Plants and Bioremediation Methods. Applied and Environmental Soil Science. Volume 2014 (2014). Article ID 752708. (pp12)

Dalvand M, Hamidiana AH, Zare Chahookib MA, Moteshare Zadeh B, Mirjalili SAA \& Esmaeil Zade E. 2014. Comparing heavy metal accumulation abilities in Artemisia aucheri and Astragalus gummifer in Darreh Zereshk region, Taft. Desert, 19(2):137-140

Dey S and Dwivedi SK. 2002. Medicinal herbs: A potential source of toxic metal exposure for man and animals in India. Archives of Environmental Health, 57(3):229-31

Dumat C, Pinelli E, Pourrut B, Shahid M \& Winterton P. 2011. Lead uptake, toxicity, and detoxification in plants. Reviews of Environmental Contamination and Toxicology, 213:113-36

Dzomba P, Chayamiti T \& Togarepi E. 2012. Heavy metal content of selected raw medicinal plant materials: Implication for patient health. Bulletin of Environment, Pharmacology and Life Sciences, 1(10):28-33

Fahr M, Bendaou N, Bogusz D, Hocher V, Laplaze L, Mzibri M \& Smouni A. 2013. Effect of lead on root growth. Frontiers in Plant Science, 4:175

Feleafel MN and Mirdad ZM. 2013. Hazard and effects of pollution by lead on vegetable crops. Journal of Agricultural and Environmental Ethics, 26(3):547567 
Lead potential bioaccumulation in two species

Gatebe E, Gitu L, Maobe M \& Rotich H. 2012. Profile of Heavy Metals in Selected Medicinal Plants Used for the Treatment of Diabetes, Malaria and Pneumonia in Kisii Region, Southwest Kenya. Global Journal of Pharmacology, 6(3):245-251

Genuis SJ and Kelln KL. 2015. Toxicant Exposure and Bioaccumulation: A Common and Potentially Reversible Cause of Cognitive Dysfunction and Dementia. Behavioral Neurology. Volume 2015 (2015), Article ID 620143. (pp10). http://dx.doi.org/10.1155/2015/620143

Ignatius A, Arunbabu V, Neethu J \& Ramasamy EV. 2014. Rhizofiltration of lead using an aromatic medicinal plant Plectranthus amboinicus cultured in a hydroponic nutrient film technique (NFT) system. Environmental Science and Pollution Research. DOI: 10.1007/s11356-014-3204-1

Jung MC and Thornton I. 1996. Heavy metal contamination of soils and plants in the vicinity of a lead-zinc mine, Korea. Applied Geochemistry, 11(1-2):53 - 59

Li N, Li Z, Mcbride MB, Xia H \& Zhuang P. 2009. Health risk from heavy metals via consumption of food crops in the vicinity of Dabaoshan mine, South Korea. The Science of the Total Environment, 407(5):1551-61

Li R, Zhou Z, Xie X, Li Y, Zhang Y \& Xu X 2016. Effects of Dissolved Organic Matter on Uptake and Translocation of Lead in Brassica chinensis and Potential Health Risk of Pb. International Journal of Environmental Research and Public Health, 13(7):687

Maziah M, Ong GH, Tan SG \& Yap CK. 2011. Heavy Metal Accumulation in a Medicinal Plant Centella asiatica from Peninsular Malaysia. Journal of Biological Sciences, 11:146-155

Mertens J, Luyssaert S \& Verheyen K. 2005. Use and abuse of trace metal concentrations in plants tissue for biomonitoring and phytoextraction. Environmental Pollution, 138:1-4

Micó C, Peris M, Recatalá L, Sánchez J \& Sánchez R. 2007. Heavy metal contents in horticultural crops of a representative area of the European Mediterranean region. The Science of the Total Environment, 378(1-2):42-48

Nazareno PA, Buot I \& Flavier ME. 2011. The plants in a landfill in the Philippines and their behavior towards lead and mercury: Their potential use for future remediation of metal-contaminated soils in the country. Journal of Environmental Science and Management, 14(1):60-70

Rezvani M and Zaefarian F. 2011. Bioaccumulation and translocation factors of cadmium and lead in Aeluropus littoralis. Australian Journal of Agricultural Engineering, 2(4):114-119

Sharma P and Dubey RS. 2005. Lead toxicity in plants. Brazilian Journal of Plant. Physiology, 17(1):35-52

Singh $\mathrm{J}$ and Kalamdhad AS. 2011. Effects of Heavy Metals on Soil, Plants, Human Health and Aquatic Life. International Journal of Research in Chemistry and Environment, 1(2):15-21

Singh S, Parihar P, Singh R, Singh VP \& Prasad SM. 2015. Heavy Metal Tolerance in Plants: Role of Transcriptomics, Proteomics, Metabolomics, and Ionomics. Frontiers in Plant Science, 6:1143. doi: 10.3389/fpls.2015.01143

Tangahu BV, Abdullah SRS, Basri H, Idris M, Anuar N \& Mukhlisin M. 2011. A Review on Heavy Metals (As, Pb, and $\mathrm{Hg}$ ) Uptake by Plants through Phytoremediation. International Journal of Chemical Engineering, vol. 2011, Article ID 939161, 31 pages, 2011. doi:10.1155/2011/93916 
Ongy \& Belonias

Verma S and Dubey RS. 2003. Lead toxicity includes lipid peroxidation and alters the activities of antioxidant enzymes in growing rice plants. Plant Science, 164:645-655

Yoon J, Xinde CAO, Qixing Zhou \& Lena Q M. 2006. Accumulation of Pb, $\mathrm{Cu}$, and Zn in native plants growing on a contaminated Florida site. The Science of the Total Environment. 368:456-464 